\title{
BASES DOGMÁTICAS PARA INTERPRETAÇÃO DOS ARTS. 317 E 478 DO NOVO CÓDIGO CIVIL BRASILEIRO ${ }^{3}$
}

\section{LAURA CORADINIFRANZ}

Data da defesa:08/12/2004

\section{RESUMO}

A presente dissertação propõe-se a analisar os institutos que tutelam o sinalagma contratual funcional, pois os contratos cuja execução protrai-se no tempo ficam expostos às vicissitudes passadas pela economia. Será objeto de discussão a problemática da alteração superveniente das circunstâncias, desde os seus fundamentos até a (re) distribuição dos riscos por ela ocasionada. Na primeira parte serão relatados os primeiros delineamentos conferidos à influência da alteração das circunstâncias: a cláusula relus sic stantibuss. o ressurgimento dessa cláusula na atualidade e os contornos a ela conferidos pelas três famílias de teorias, da tradição romano-germânica, que buscam fundamentar a revisão ou a resolução do contrato quando a prestação tornar-se desequilibrada: Teoria da Imprevisão, cunhada na França, Teoria da Quebra da Base do Negócio, formulada na Alemanha, e a Teoria da Excessiva Onerosidade da Prestação, desenvolvida na Itália, bem como os reflexos dessas teorias no direito europeu dos contratos. Na segunda parte serão, por sua vez, analisadas as soluções propostas pelo novo Código Civil brasileiro para a one osidade superveniente das prestações de contratos com execução diferida e continuada, os seus fundamentos e respectivas eficácias. Palavras-Chave: Contrato. Excessiva Onerosidade. Revisão. Resolução.

3 A banca foi composta pelo Professor Doutor Renan Lotufo, Professor da Pontifícia Universidade Católica de São Paulo e Doutor em Direito pela Pontifícia Universidade Católica de São Paulo; pelo Professor Doutor Eugênio Facchini Neto, Professor da Pontifícia Universidade Católica do Rio Grande do Sul e Doutor em Direito pela Università Degli Srudi Di Firenzi, Firenze - Itália; e pelo Professor Doutor Cláudio Fortunato Michelon Junior, Professor da Universidade Federal do Rio Grande do Sul e Doutor em Teoria e Filosofia do Direito pela Universidade de Edimburgo, EU, Grã. Bretanha, A referida defesa foi presidida pela Professora Doutora Judith Hofmeister Martins-Costa, Professora Adjunta da Universidade Federal do Rio Grande do Sul e Doutora em Direito e Livre Docente pela Universidade de São Paulo, orientadora do referido trabalho. 